Vol. 1, No. 1, Juli 2017, 21-31

Available Online at https://ejournal.warmadewa.ac.id/index.php/kulturistik DOI: http://dx.doi.org/10.22225/kulturistik.1.1.214

\title{
PEMAKAIAN BAHASA OLEH MASYARAKAT BUGIS DI DESA SENGANAN, TABANAN, BALI
}

\author{
I Made Suparta \\ IKIP Saraswati Tabanan \\ madesuparta831@yahoo.co.id \\ I Nyoman Kardana \\ Universitas Warmadewa \\ ikardana@yahoo.com
}

\begin{abstract}
ABSTRAK
Penelitian pemakaian bahasa Bugis pada masyarakat Bugis di Desa Senganan, mengkaji keberadaan bahasa Bugis sebagai bahasa minoritas di Bali. Penelitian ini membahas tentang pemakaian bahasa berdasarkan ranah-ranah penggunaan bahasa masyarakat Bugis dan faktor-faktor yang menyebabkan terjadinya pergeseran bahasa Bugis di Desa Senganan. Teori yang digunakan dalam penelitian ini adalah teori pilihan bahasa dan teori pergeseran bahasa. Hasil penelitian ini menunjukkan bahwa pemakaian bahasa pada masyarakat Bugis di Desa Senganan yang didasarkan atas ranah keluarga, ranah agama, ranah ketetanggaan, ranah pemerintahan, dan ranah pendidikan, baik secara kualitatif maupun kuantitatif tidak ditemukan adanya penggunaan bahasa Bugis. Pemakaian bahasa didominasi oleh bahasa Bali dan bahasa Indonesia. Dengan demikian dapat dikatakan bahwa bahasa Bugis pemakaiannya telah mengalami pergeseran di desa Senganan. Faktor -faktor yang menyebabkan terjadinya pergeseran bahasa Bugis di Desa Senganan adalah faktor internal penutur yang meliputi ketidaksinambungan pengalihan bahasa ibu, proses adaptasi/pembauran dan sikap bahasa komunitas Bugis di desa Senganan; faktor eksternal meliputi lingkungan geografi pemukiman yang menyatu dengan masyarakat sekitarnya dan lingkungan bahasa sekitarnya (ekologi bahasa) yang mayoritas menggunakan bahasa Bali.
\end{abstract}

Kata Kunci: pemakaian bahasa, pergeseran bahasa, bahasa Bugis, ranah

\begin{abstract}
[Title: The language use by Bugisnese community at Senganan Village, Tabanan, Bali] This research is about language use by the Bugisnese community at Senganan Village, Penebel District, Tabanan as a minority ethnic group in Bali. The research discusses the use of languages among the different domains and factors causing the language shift at Senganan Village. Theory used in this research is the theory of bilingualism, the theory of language choice and the theory of language shift. The result shows that the use of Bugesness language is not found on different observed domains, such as domains family, religion, neighborhood, administration, and education. The use of Balinese and Indonesian dominated their language uses in all domains. Thus, it can be concluded that Bugisnese language is not used anymore by the community or its use has already shifted. The factors causing the shift of Bugisnese language at the village is internally related to the attitude of the speakers covering unsustainable transfer of the mother tongue and the unfaithfulness to the mother tongue, and externally it deals with the factor consisting of geographic environment of the village surrounded by vullages of which people mostly speak Balinese language.
\end{abstract}

Keywords: language use, language shift, Bugisnese community, domain 


\section{PENDAHULUAN}

Masyarakat Bali tergolong masyarakat majemuk karena terdiri atas berbagai suku (etnis) dengan latar budaya yang berbeda-beda. Masing-masing etnis mempunyai bahasa sendiri yang hidup berkelompok atau berbaur dengan kelompok masyarakat sekitarnya. Fungsi bahasa tersebut dalam kedudukannya sebagai bahasa daerah adalah alat komunikasi utama dalam keluarga, maupun dengan keluarga lain dalam kehidupan sehari-hari. Selain itu bahasa daerah juga merupakan lambing kebanggaan daerah dan lambang identitas daerah asal etnis tersebut.

Kondisi masyarakat yang multietnik merupakan faktor pendorong bagi seseorang untuk menguasai lebih dari satu bahasa selain bahasa daerah dan bahasa etnisnya. Dengan menguasai lebih dari satu bahasa akan memberi peluang yang lebih besar kepada seseorang untuk mengadakan komunikasi di dalam usaha mendekatkan diri dengan lingkungannya.

Bahasa merupakan ciri penting untuk menentukan identitas keetnisan suatu kelompok, tetapi tampaknya bahasa tidak selalu dapat dipertahankan oleh kelompoknya, terutama dalam masyarakat multilingual. Kontak bahasa dapat mengakibatkan terjadinya pergeseran bahasa. Pergeseran bahasa merupakan akibat dari pilihan bahasa dalam jangka panjang dan bersifat kolektif. Pergeseran bahasa menunjukkan adanya suatu bahasa yang benar-benar ditinggalkan oleh komunitas penuturnya. Bila pergeseran sudah terjadi, anggota suatu komunitas bahasa secara kolektif lebih memilih bahasa baru (Fasold, 1984:213-214).

Objek penelitian ini adalah masyarakat Bugis di Desa Senganan, Tabanan, Bali. Keberadaan komunitas Bugis di Desa Senganan diperkirakan sudah ada sejak tahun 1900-an. Mereka tinggal membaur dikelilingi oleh masyarakat sekitarnya dari etnis Bali yang berbahasa Bali. Sebagai pendatang mereka hidup berdampingan dengan etnis mayoritas Bali dalam satu ikatan banjar dinas. Semua kegiatan yang berhubungan dengan kedinasan dilakukan bersama-sama yang dipimpin oleh seorang kepala dusun.

Berdasarkan hasil observasi awal, dapat diketahui bahwa ada kecendrungan masyarakat Bugis di desa Senganan tidak lagi menggunakan bahasa Bugis dalam berkomunikasi. Mereka lebih memilih menggunakan bahasa Bali akibat kuatnya pengaruh bahasa mayoritas, bahasa sekitarnya. Gejala pergeseran bahasa Bugis ke bahasa Bali di desa Senganan disebabkan oleh beberapa faktor yang saling berkaitan, baik faktor internal maupun eksternal penuturnya. Terdesaknya bahasa minoritas ini menjadi semakin rumit karena kehadiran bahasa Indonesia yang dominan akibat pengaruh media massa atau semakin banyak warga Bugis yang merantau ke luar daerah. Fenomena kebahasaan ini merupakan keunikan tersendiri yang menarik untuk diteliti. Oleh karena itu, kajian yang mendalam terhadap permasalahan pemakaian bahasa berdasarkan ranah-ranah penggunaan bahasa masyarakat Bugis serta faktor-faktor yang menyebabkan terjadinya pergeseran bahasa Bugis di Senganan menjadi hal yang penting untuk dilakukan.

\section{METODE}

Tulisan ini termasuk penelitian lapangan mengenai pergeseran bahasa Bugis pada masyarakat Bugis di Desa Senganan. Pengumpulan data menggunakan metode simak, survei, dan metode cakap (Mahsun, 2013:242 253). Metode simak dapat disejajarkan dengan metode pengamatan atau observasi. Metode simak secara oprasional dibantu dengan teknik simak libat cakap, 
perekaman dan pencatatan. Metode ini digunakan untuk mendapatkan data tentang pilihan bahasa. Metode survei dilakukan melalui penyebaran kuesioner atau daftar pertanyaan terstruktur untuk memperoleh data tentang tingkat kekerapan pemakaian bahasa pada masing-masing ranah. Metode cakap dapat disejajarkan dengan metode wawancara (interview). Metode ini dilakukan untuk memperoleh data tentang faktor-faktor yang menyebabkan terjadinya pergeseran bahasa Bugis.

Setelah data terkumpul kemudian dianalisis dengan menggunakan metode kualitatif dan kuantitatif. Data sosiolinguistik terkait pemakaian bahasa serta faktor-faktor yang menyebabkan pergeseran bahasa memerlukan analisis deskripsi dan interpretasi secara kualitatif sedangkan penentuan kekerapan pilihan bahasa memerlukan analisis secara kuantitatif.

Hasil analisis disajikan dengan menggunakan metode formal dan informal. Metode formal direalisasikan dalam bentuk lambang atau tanda-tanda dan meode informal diwujujudkan dengan dengan cara mendeskripsikannya dengan katakata biasa (Sudaryanto, 1993:145).

\section{PEMBAHASAN}

Kajian ini membahas salah satu topik dalam bidang sosiolinguistik, yaitu pemakaian, khususnya tentang pergeseran bahasa. Teori yang diterapkan untuk untuk memecahkan masalah ini adalah teori sosiolinguistik, khususnya teori pilihan bahasa dan pergeseran bahasa. Keterpilihan suatu bahasa atau variasi bahasa tidak bisa lepas dari konteks institusional tertentu yang disebut ranah atau domain. Ranah merupakan konstruksi sosial budaya yang diabstraksikan dari partisipan, lokasi, dan topik (Fishman, 1972:22-24).

Pilihan bahasa berakibat pada munculnya gejala kebertahanan atau pergeseran bahasa. Pergeseran bahasa terjadi apabila guyub memilih bahasa baru dalam ranah yang semula diperuntukkan bagi bahasa lama. Ranah-ranah itu mulai "bocor" dan bahasa yang mayoritas merembes masuk menggantikan fungsi bahasa minoritas. Apabila pergeseran itu berlangsung secara total dalam jangka panjang, paling tidak tiga generasi dan bersifat kolektif akan membawa konsekuensi kepunahan bahasa. Bahasa minoritas sudah tidak berfungsi lagi pada semua ranah dan digantikan oleh bahasa mayoritas (Holmes, 1992:61 dalam Sumarsono, 1990 :154).

\section{Pemakaian Bahasa Pada Masyarakat Bugis Di Desa Sengan, Tabanan, Bali}

Dalam tulisan ini pembahasan pemakaian atau pilihan bahasa masyarakat Bugis yang bermukim di Desa Senganan dibatasi pada ranah keluarga (family domain), ranah agama (religion domain), ranah ketetanggaan (neighbourhood domain), ranah pemerintahan (governmental domain), dan ranah pendidikan (education domain).

Pemakaian atau pilihan bahasa dalam ranah keluarga pada masyarakat Bugis di Desa Senganan menggambarkan bahasa atau ragam bahasa yang mereka gunakan dalam peristiwa keluarga. Peristiwa kegiatan berbahasa dapat terjadi antara anak, bapak, ibu, kakek dan nenek. Suasana tuturan berlangsung santai. Berikut ini disajikan contoh wacana pemakaian bahasa di dalam ranah keluarga masyarakat Bugis di Desa Senganan.

$\begin{array}{ll}\text { Tempat } & \text { : Ruang Tamu Keluarga } \\ \text { Topik } & \text { : Nasehat } \\ \text { Partisipan } & \text { : Bapak - Anak }\end{array}$


Vol. 1, No. 1, Juli 2017, 24

Available Online at https://ejournal.warmadewa.ac.id/index.php/kulturistik DOI: http://dx.doi.org/10.22225/kulturistik.1.1.214

$\begin{array}{rll}\text { Bapak (P1) } & \text { : Sing melajah } & \text { Yun? } \\ & \text { Tidak belajar } & \text { Yun? } \\ \text { Anak }(\mathrm{P} 2) & : \text { Suba san } & \text { Wak. } \\ & \text { Sudah tadi } & \text { Pak. } \\ \text { (P1) } & \text { Kapahin } & \text { mebalih tv! } \\ & \text { Jangan terlalu sering } & \text { nonton tv! } \\ \text { (P2) } & : \text { Nah, mara san } & \text { ngontak. } \\ & \text { Ya, baru tadi } & \text { menghidupkan. }\end{array}$

Pemakaian bahasa dalam ranah keluarga masyarakat Bugis di desa Senganan dapat dilihat dalam tabel di bawah ini.

Tabel 1 Kekerapan Pemakaian Bahasa di Dalam Ranah Keluarga

\begin{tabular}{ccc}
\hline Pilihan Bahasa & Kekerapan & Persentase \\
\hline BB & 100 & $98 \%$ \\
BG & 0 & $0 \%$ \\
BI & 2 & $2 \%$ \\
BL & 0 & $0 \%$ \\
Jumlah & 102 & $100 \%$ \\
\hline
\end{tabular}

Pemakaian bahasa dalam ranah keluarga didominasi oleh bahasa Bali dengan tingkat kekerapan pilihan sebanyak 98\%. Pilihan bahasa Indonesia menempati urutan kedua dengan jumlah yang sangat kecil, yakni $2 \%$. Pilihan terhadap bahasa Bugis dan bahasa lain sama sekali tidak ditemukan, yakni $0 \%$.

Pemakaian bahasa dalam ranah agama diharapkan dapat menjaring data bahasa yang berkaitan dengan topik-topik tradisional yang ada hubungannya dengan keagamaan, adat dan budaya. Pemakaian bahasa dalam ranah agama pada masyarakat Bugis dapat dilihat dalam wacana di bawah ini.
Tempat
: Halaman Masjid
Topik
: Nyekar ke Kuburan
Partisipan : Remaja Masjid
Adit (P1): "Assalamu' alaikum Warohmatullahi Wabarokaatuh".
Ansul (P2): "Wa'alaikumsalam Warohmatullahi Wabarokaatuh'.
(P1): Nyanan jam kuda nyekar Sul? Nanti jam berapa nyekar Sul?
(P2): Nyanjaang, jam lima Sorean jam lima.

Penggunaan bahasa pada masyarakat Bugis dalam ranah agama dapat dilihat dalam tabel di bawah ini.

Tabel 2 Kekerapan Pemakaian Bahasa di Dalam Ranah Agama

\begin{tabular}{ccc}
\hline Pilihan Bahasa & Kekerapan & Persentase \\
\hline BB & 89 & $87 \%$ \\
BG & 0 & $0 \%$ \\
BI & 13 & $13 \%$ \\
BL & 0 & $0 \%$ \\
Jumlah & 102 & $100 \%$ \\
\hline
\end{tabular}


Vol. 1, No. 1, Juli 2017, 25

Available Online at https://ejournal.warmadewa.ac.id/index.php/kulturistik DOI: http://dx.doi.org/10.22225/kulturistik.1.1.214

Pemakaian bahasa dalam ranah agama didominasi oleh bahasa Bali, yaitu sejumlah $87 \%$. Pilihan terhadap bahasa Indonesia menempati urutan kedua dengan kekerapan mencapai $13 \%$. Dalam ranah agama para responden sama sekali tidak menunjukkan pilihan terhadap bahasa Bugis dan bahasa lain.

Pemakaian bahasa dalam ranah ketetanggaan dimaksudkan untuk mendapatkan gambaran penggunaan bahasa oleh warga Bugis apabila mengadakan komunikasi verbal dengan tetangga yang ada di sekitar tempat mereka. Topiknya adalah hal-hal yang berhubungan dengan pusat perhatian bersama yang ada di sekitarnya. Untuk lebih jelasnya mengenai pilihan bahasa dalam ranah ketetanggaan dapat dilihat dalam wacana di bawah ini.

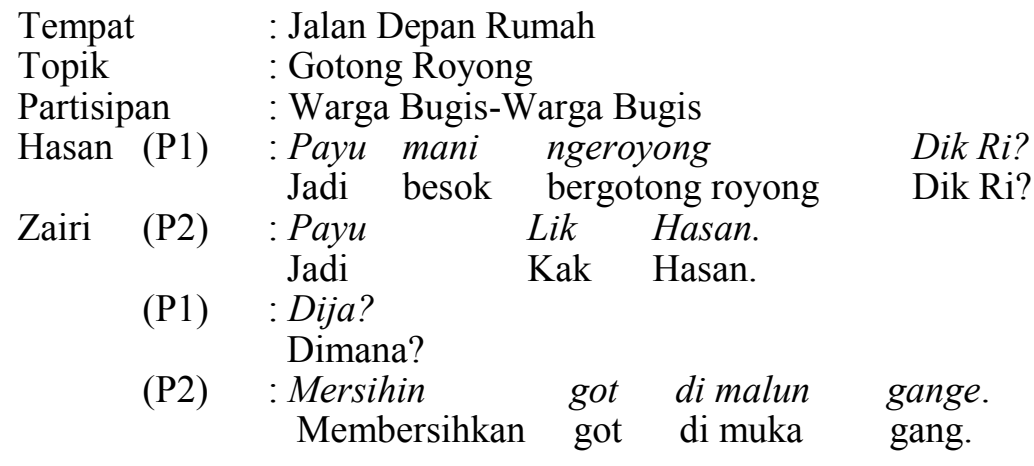

Penggunaan bahasa dalam ranah ketetanggaan pada masyarakat Bugis di Desa Senganan didominasi oleh bahasa Bali. Setelah dikaji kekerapan dan persentasenya dapat dilihat dalam tabel di bawah ini.

Tabel 3 Kekerapan Pemakaian Bahasa di Dalam Ranah Ketetanggaan

\begin{tabular}{ccc}
\hline Pilihan Bahasa & Kekerapan & Persentase \\
\hline BB & 101 & $99 \%$ \\
BG & 0 & $0 \%$ \\
BI & 1 & $1 \%$ \\
BL & 0 & $0 \%$ \\
Jumlah & 102 & $100 \%$ \\
\hline
\end{tabular}

Pemakaian bahasa dalam ranah ketetanggaan didominasi oleh bahasa Bali dengan tingkat kekerapan sebanyak 99\%. Pilihan kedua ditempati oleh bahasa Indonesia dengan jumlah yang sangat kecil, yakni $1 \%$. Selanjutnya, untuk kekerapan pemakaian bahasa Bugis dan bahasa lain tidak ditemukan sama sekali atau $0 \%$.

Pemakaian bahasa dalam ranah pemerintahan dimaksudkan untuk mengetahui bahasa apa yang dipakai masyarakat Bugis di Desa Senganan apabila mereka mau berhubungan atau berurusan dengan instansi pemerintah atau aparat pemerintah. Topik yang dibahas dalam ranah pemerintahan adalah hal-hal yang berkaitan dengan KTP, beras raskin, dan lain-lain. Berikut ini akan disajikan contoh wacana pemakaian bahasa di dalam ranah pemerintahan masyarakat Bugis di Desa Senganan. 
Vol. 1, No. 1, Juli 2017, 26

Available Online at https://ejournal.warmadewa.ac.id/index.php/kulturistik DOI: http://dx.doi.org/10.22225/kulturistik.1.1.214

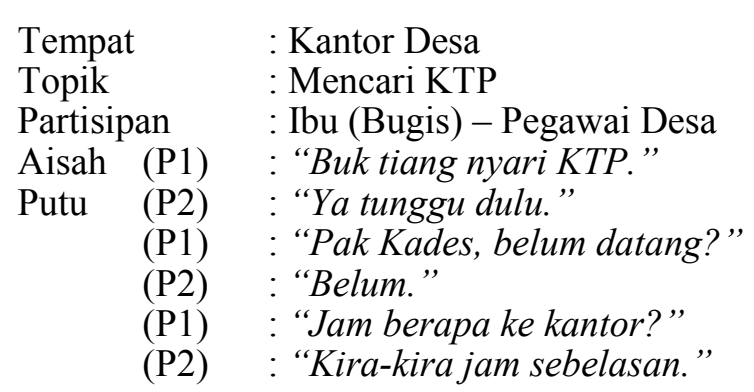

Pemakaian bahasa dalam ranah pemerintahan masyarakat Bugis di Desa Senganan lebih dominan menggunakan bahasa Indonesia. Setelah dikaji kekerapan dan persentasenya dapat dilihat dalam tabel di bawah ini.

Tabel 4 Kekerapan Pemakaian Bahasa di Dalam Ranah Pemerintahan

\begin{tabular}{ccc}
\hline Pilihan Bahasa & Kekerapan & Persentase \\
\hline BB & 40 & $39 \%$ \\
BG & 0 & $0 \%$ \\
BI & 62 & $61 \%$ \\
BL & 0 & $0 \%$ \\
Jumlah & 102 & $100 \%$ \\
\hline
\end{tabular}

Pilihan bahasa para responden dalam ranah pemerintahan didominasi oleh bahasa Indonesia dengan tingkat kekerapan sebanyak 61\%. Pilihan bahasa Bali menempati urutan kedua dengan kekerapan sebanyak 39\%. Selanjutnya, untuk kekerapan bahasa Bugis dan bahasa lain tidak ditemukan sama sekali atau $0 \%$.

Pemakaian bahasa dalam ranah pendidikan mengambil lokasi di lingkungan sekolah baik di dalam maupun di luar kelas. Masyarakat Bugis di Desa Senganan tidak mempunyai sekolah khusus bagi warga mereka. Oleh karena itu, proses pendidikan yang mereka alami di sekolah adalah sama dengan proses pendidikan yang dialami oleh warga setempat.

Berikut ini akan disajikan contoh wacana penuturan di dalam ranah pendidikan pada masyarakat Bugis di Desa Senganan.

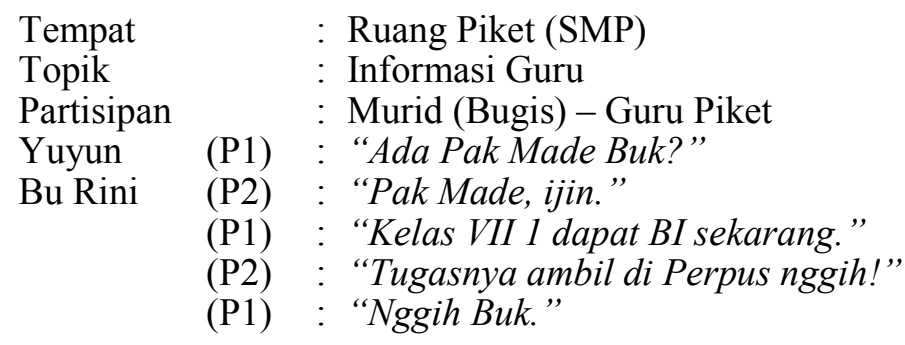

Penggunaan bahasa dalam ranah pendidikan oleh masyarakat Bugis di Desa Senganan dapat dilihat dalam tabel di bawah ini. 


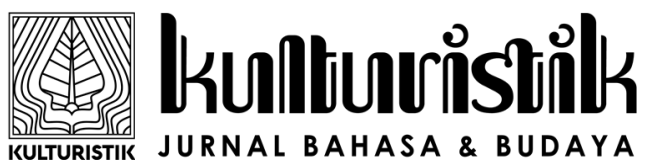

Vol. 1, No. 1, Juli 2017, 27

Available Online at https://ejournal.warmadewa.ac.id/index.php/kulturistik DOI: http://dx.doi.org/10.22225/kulturistik.1.1.214

Tabel 3.5 Kekerapan Pemakaian Bahasa di Dalam Ranah Pendidikan

\begin{tabular}{ccc}
\hline Pilihan Bahasa & Kekerapan & Persentase \\
\hline BB & 40 & $39 \%$ \\
BG & 0 & $0 \%$ \\
BI & 62 & $61 \%$ \\
BL & 0 & $0 \%$ \\
Jumlah & 102 & $100 \%$ \\
\hline
\end{tabular}

Pemakaian bahasa para responden pada ranah pendidikan didominasi oleh bahasa Indonesia dengan tingkat kekerapan sebanyak 61\%. Pilihan bahasa Indonesia menempati urutan kedua dengan tingkat kekerapan 39\%. Pada ranah pendidikan tidak ditemukan pilihan terhadap bahasa Bugis dan bahasa lain, yakni $0 \%$.

\section{Faktor-Faktor Penyebab Pergeseran Pemakaian Bahasa Bugis}

Bahasa itu bersifat dinamis. Keterkaitan bahasa dengan penuturnya mengakibatkan bahasa itu selalu berubah. Sebuah bahasa dapat bertahan atau punah tidak ditentukan oleh faktor tunggal melainkan banyak dan beragam yang merupakan mata rantai yang saling berkaitan ( (Dorin, 1979 dalam Sumarsono, 1990 :183-184). Pergeseran pemakaian bahasa Bugis pada masyarakat Bugis di Desa Senganan ditentukan oleh beberapa faktor, baik faktor yang bersumber dari dalam masyarakat penutur itu sendiri maupun dari luar penutur itu sendiri (faktor internal maupun faktor eksternal). Faktor internal yang dimaksud dalam tulisan ini meliputi ketidaksinambungan pengalihan bahasa ibu, proses adaptasi/ pembauran, sikap bahasa masyarakat Bugis. Faktor eksternal menyangkut lingkungan geografis pemukiman dan lingkungan bahasa sekitar (ekologi bahasa).

Kesinambungan pengalihan bahasa ibu merupakan faktor yang penting dalam menentukan kebertahanan atau pergeseran bahasa. Maksudnya, jika pengalihan bahasa ibu berlangsung dengan baik maka bahasa itu akan bertahan. Sebaliknya jika pengalihan bahasa itu tidak berlangsung dengan baik akan terjadi pergeseran pemakaian bahasa.

Komunitas etnis Bugis yang bermukim di desa Senganan merupakan kelompok minoritas dengan jumlah yang tidak begitu besar. Proses komunikasi sehari-hari baik formal maupun non-formal menggunakan bahasa Bali atau bahasa Indonesia. Intensitas pemakaian kedua bahasa ini sangat tinggi sehingga hampir tidak ada peluang pengalihan bahasa ibu (bahasa Bugis) kepada generasi yang lebih muda.

Ranah keluarga yang sebenarnya merupaka benteng pertahanan bahasa yang paling kuat ternyata tidak mampu menempatkan bahasa Bugis sebagai bahasa sehari-hari. Secara formal tidak ada pengalihan bahasa Bugis kepada generasi berikutnya. Hal ini terjadi karena masyarakat Bugis tidak memiliki sekolah khusus tetapi mereka bersekolah pada sekolah-sekolah negeri dan swasta yang tidak mengajarkan bahasa Bugis. Keadaan ini dapat mempercepat tergesernya bahasa Bugis di desa Senganan. Mereka telah beralih mengajarkan bahasa Bali kepada anak-anak dalam keluarga. Hal ini dapat diketahui dari jawaban dan pengakuan yang diberikan oleh tiga puluh empat responden ketika ditanya, "Bahasa apakah yang diajarkan kepada anak-anak dalam keluarga mereka? Jawabannya adalah seluruhnya, yakni $100 \%$ adalah bahasa Bali. Untuk lebih jelasnya secara rinci 
Vol. 1, No. 1, Juli 2017, 28

Available Online at https://ejournal.warmadewa.ac.id/index.php/kulturistik DOI: http://dx.doi.org/10.22225/kulturistik.1.1.214

dapat dilihat dalam tabel berikut.

Tabel 6 Bahasa Yang Dialihkan Kepada Anak-Anak Dalam Keluarga

\begin{tabular}{ccc}
\hline Bahasa & Frekuensi & Persentase \\
\hline BB & 34 & $100 \%$ \\
BG & 0 & $0 \%$ \\
BI & 0 & $0 \%$ \\
BL & 0 & $0 \%$ \\
Jumlah & 34 & $100 \%$ \\
\hline
\end{tabular}

Berdasarkan uraian di atas, dapat dikatakan bahwa upaya kesinambungan bahasa Bugis sebagai bahasa ibu tidak berlangsung dengan baik. Gejala ini merupakan faktor penting yang dapat mempercepat pergeseran bahasa Bugis di desa Senganan dan pada gilirannya digantikan oleh bahasa mayoritas, yaitu bahasa Bali.

Semua unsur kebudayaan pada suatu waktu pasti akan mengalami perubahan karena berbagai macam sebab. Salah satu penyebab itu adalah perubahan lingkungan yang dapat menuntut perubahan kebudayaan (Haviland, 1993:251 dalam Katalina, 2000 :83). Masyarakat Bugis memiliki kebudayaan tersendiri dan berkembang menyesuaikan dengan kebudayaan setempat.

Masyarakat Bugis di desa Senganan sebagai komunitas kecil memiliki kesadaran terhadap kepentingan bersama. Mereka sadar, bahwa sebagai kelompok pendatang harus mampu menyesuaikan diri dengan keadaan dan budaya Bali sehingga dalam kehidupan sehari-hari bisa berbaur akrab dengan penduduk lokal. Berikut adalah pernyataan salah seorang informan tentang hal itu.

"Bahasa yang kami gunakan dalam pergaulan sehari-hari adalah bahasa Bali dan kadang-kadang bahasa Indonesia kalau mau mengurus surat-surat di kantor. Sekarang warga Bugis di sini sudah tidak ada yang bisa berbahasa Bugis. Anak-anak sejak kecil sudah diajari berbahasa Bali" (Jameri, 55 tahun).

Alasan masyarakat Bugis menggunakan bahasa Bali dalam kehidupan sehari-hari dapat dilihat dalam tabel berikut.

Tabel 7 Alasan Warga Bugis Menggunakan Bahasa Bali

\begin{tabular}{cccc}
\hline No. & Alasan Menggunakan Bahasa Bali & Frekuensi & Persentase \\
\hline 1. & Lingkungan menggunakan bahasa Bali & 10 & $29 \%$ \\
2. & Memudahkan pergaulan dengan lingkungan & 20 & $59 \%$ \\
3. & Lebih merasa menyatu dengan orang Bali & 4 & $12 \%$ \\
& Jumlah & 34 & $100 \%$ \\
\hline
\end{tabular}

Ketiga alasan yang diberikan oleh responden menunjukkan, bahwa pemakaian bahasa Bali oleh masyarakat Bugis di desa Senganan dimaksudkan untuk memudahkan pergaulan dan mempunyai motivasi untuk dapat berbaur dengan masyarakat Bali yang ada di sekitarnya. Adanya keinginan yang kuat dari masyarakat Bugis di desa Senganan untuk beradaptasi/membaur mempunyai dampak positif bagi keamanan, kenyamanan, dan toleransi di daerah ini. Terlebih 
Vol. 1, No. 1, Juli 2017, 29

Available Online at https://ejournal.warmadewa.ac.id/index.php/kulturistik DOI: http://dx.doi.org/10.22225/kulturistik.1.1.214

lagi tidak adanya hambatan bahasa dalam mengkomunikasikan permasalahan mereka karena baik etnis Bali maupun etnis Bugis sama-sama menggunakan bahasa Bali sebagai bahasa pergaulan sehari-hari. Di sisi lain, hal itu mempunyai dampak yang kurang positif bagi budaya etnis mereka, terutama bahasanya.

Sikap bahasa (language attitude) adalah tata keyakinan yang relatif berjangka panjang mengenai bahasa dan objek tertentu, yang memberikan kecendrungan kepada seseorang untuk bereaksi dengan cara tertentu yang disenanginya (Suandi, 2014:151). Sikap bahasa merupakan sikap penutur terhadap bahasa itu sendiri yang menyangkut bagaimana pengetahuan tentang bahasa itu, perasaan dalam menggunakan bahasa tersebut, atau tindakan-tindakan apa yang dilakukan untuk melestarikan dan mempertahankan bahasa tersebut. Sikap bahasa sebenarnya menyangkut tanggung jawab penutur bahasa terhadap bahasanya.

Sikap positif terhadap bahasa lebih banyak dilihat dari pelaksanaan pemakaian bahasa dalam kehidupan sehari-hari. Pemakai bahasa yang mempunyai sikap positif terhadap bahasanya menganggap bahasa sebagai kebutuhan pribadi dan perlu dipelihara serta dijaga kelestariannya.

Sikap bahasa masyarakat Bugis di desa Senganan terhadap bahasanya menunjukkan sikap tidak positif. Tidak digunakannya bahasa Bugis dalam berkomunikasi oleh masyarakat Bugis mengindikasikan, bahwa mereka sudah tidak terlalu memperdulikan bahasa leluhurnya. Dalam berkomunikasi sehari-hari mereka menggunakan bahasa Bali atau bahasa Indonesia. Ketika ditanyakan kemampuan menggunakan bahasa Bugis, seluruh responden menjawab "Tidak mampu". Memang kenyataannya, selama pengamatan di lapangan tidak pernah didengar warga Bugis menggunakan bahasa Bugis bila berkomunikasi antarsesamanya. Kemampuan menggunakan bahasa Bugis masyarakat Bugis dapat dilihat dalam tabel di bawah ini.

Tabel 8 Kemampuan Berbahasa Bugis

\begin{tabular}{clcc}
\hline No. & Kemampuan Berbahasa Bugis Masyarakat Bugis & Frekuensi & Persentase \\
\hline 1. & Sangat mampu & - & - \\
2. & Mampu tetapi tidak terlalu fasih & - & - \\
3. & Tidak mampu sama sekali & 34 & $100 \%$ \\
& Jumlah & 34 & $100 \%$ \\
\hline
\end{tabular}

Ketidakmampuan warga Bugis dalam menggunakan bahasa asalnya juga terlihat dari tidak adanya pembinaan bahasa Bugis yang dilakukan oleh para tokoh masyarakat. Upaya pembinaan bahasa Bugis perlu segera dilaksanakan karena akan dapat menimbulkan sikap bangga dan sadar dengan bahasanya. Jika masyarakat sudah bangga dan sadar dengan bahasanya sendiri akan dapat membendung laju pergeseran bahasa Bugis di desa Senganan.

Sikap bahasa juga dapat dilihat dari pikiran atau perasaan penutur bahasa tersebut (Fasold, 1984:148). Komunitas Bugis sudah cukup lama menggunakan bahasa Bali sebagai bahasa pergaulan sehari-hari. Ketika mereka ditanyakan tentang perasaannya atau pendapatnya mengenai pemakaian bahasa Bali, responden memberikan tanggapan positif. Hampir sebagian besar memberikan jawaban "senang" dengan frekuensi sebanyak 30 atau 88\%. Untuk lebih jelasnya dapat dilihat tabel berikut. 


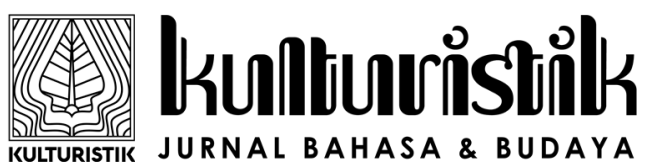

Vol. 1, No. 1, Juli 2017, 30

Available Online at https://ejournal.warmadewa.ac.id/index.php/kulturistik DOI: http://dx.doi.org/10.22225/kulturistik.1.1.214

Tabel 9 Tanggapan Masyarakat Bugis terhadap Penggunaan Bahasa Bali

\begin{tabular}{|c|c|c|c|}
\hline No. & $\begin{array}{c}\text { Tanggapan Masyarakat Bugis Terhadap } \\
\text { Pemakaian Bahasa Bali Sebagai Alat Komunikasi } \\
\text { Sehari-hari }\end{array}$ & Frekuensi & Persentase \\
\hline 1. & Marah & - & - \\
\hline 2. & Senang & 30 & $88 \%$ \\
\hline 3. & Biasa-biasa saja & 4 & $12 \%$ \\
\hline 4. & Tidak menjawab & - & - \\
\hline \multicolumn{2}{|r|}{ Jumlah } & 34 & $100 \%$ \\
\hline
\end{tabular}

Berdasarkan uraian di atas dapat disimpulkan, bahwa masyarakat Bugis di desa Senganan memiliki sikap bahasa yang negatif terhadap bahasa Bugis. Sebaliknya mereka memiliki sikap positif terhadap bahasa Bali dan hampir seluruhnya menyatakan senang menggunakannya. Kondisi ini mendorong terjadinya pergeseran pemakaian bahasa Bugis di daerah ini.

Suatu kelompok komunitas, yang menempati wilayah kecil dan secara geografis relatif terpisah dari warga komunitas di luar kelompoknya, merupakan dukungan nyata dan kuat terhadap kurangnya intensitas kontak fisik dan kontak bahasa sehari-hari antara kelompok minoritas dan kelompok mayoritas. Hal itu tentu memberikan kesempatan yang relatif lebih luas kepada anggota kelompoknya untuk melakukan interaksi verbal dengan menggunakan bahasa ibu atau bahasa etnisnya (Sumarsono, 1990:225). Wilayah pusat pemukiman penutur sebuah bahasa merupakan faktor yang penting menentukan bertahan tidaknya suatu bahasa.

Masyarakat Bugis di Banjar Dinas Soka Kanginan, Desa Senganan hidup berdampingan dengan tempat tinggal orang Bali. Mereka hidup membaur berada dalam satu ikatan banjar dinas. Adanya lingkungan alam yang tidak terpisahkan ini menyebabkan sering terjadi kontak sosial antara etnis Bugis dengan etnis Bali. Dalam kegiatan kedinasan mereka melakukan bersama-sama, seperti rapat banjar dinas, kegiatan PKK, gotong royong dan sebagainya. Tradisi ngejot yang merupakan warisan budaya Bali masih berlangsung sampai sekarang, terutama pada perayaan hari-hari besar baik umat Hindu maupun Islam. Dengan demikian dapat dikatakan, bahwa lingkungan alam pemukiman yang menyatu antara kedua etnis dapat memicu terjadinya pergeseran bahasa Bugis.

Lingkungan bahasa sekitar (ekologi bahasa) dapat mempengaruhi keberadaan sebuah bahasa. Lingkungan bahasa sekitar ini terkait erat dengan lingkungan alam seperti telah diuraikan di depan. Maksudnya secara geografis wilayah pusat pemukiman penutur bahasa Bugis dikelilingi oleh wilayah hunian orang Bali sebagai penutur bahasa Bali. Masyarakat Bugis di daerah ini merupakan etnis minoritas. Menurut kepala Dusun Bapak Ketut Sudiarta, jumlah keseluruhan penduduk Banjar Dinas Soka Kanginan, Desa Senganan sebanyak 637 orang dengan rincian 593 orang berasal dari etnis Bali dan sisanya 44 orang dari etnis Bugis. Melihat kondisi ini, ada kecendrungan warga Bugis untuk menguasai bahasa Bali sebagai konsekuensi pengaruh lingkungan bahasa sekitar, yaitu bahasa Bali. Hal ini sesuai pula dengan alasan yang diberikan oleh tiga puluh empat orang responden, bahwa mereka mengajarkan bahasa Bali atau menggunakan bahasa Bali dalam keluarga karena alasan memudahkan pergaulan dan lingkungan masyarakat yang rata-rata menggunakan bahasa Bali. 


\section{SIMPULAN}

Berdasarkan hasil analisis dari data yang dikumpulkan melalui responden di lapangan maka dalam penelitian ini dapat dibuat beberapa kesimpulan.

1. Dalam penelitian pergeseran bahasa Bugis pada masyarakat Bugis di Desa Senganan dideskripsikan lima ranah pemakaian bahasa atau pilihan bahasa. Kelima ranah tersebut adalah ranah keluarga, ranah agama, ranah ketetanggaan, ranah pemerintahan dan ranah pendidikan. Dari lima ranah tersebut, ternyata bahasa Bugis sudah tidak dipergunakan lagi sebagai alat komunikasi verbal dengan lawan bicaranya. Dalam ranah keluarga, ranah agama, dan ranah ketetanggaan pemakaian bahasa didominasi oleh bahasa Bali sedangkan pilihan terhadap bahasa Indonesia ditemukan dalam jumlah yang relatif kecil. Dalam ranah pemerintahan dan pendidikan pemakaian bahasa didominasi oleh bahasa Indonesia sedangkan pilihan kedua ditempati oleh bahasa Bali.

2. Masyarakat Bugis di Desa Senganan ditemukan menggunakan dua bahasa, yakni bahasa Bali dan bahasa Indonesia. Dari segi kualitas dan kuantitas bahasa Bali lebih dominan daripada bahasa Indonesia. Hal ini mengindikasikan, bahwa keberadaan bahasa Bugis di Desa Senganan, Kecamatan Penebel, Kabupaten Tabanan sudah mengalami pergeseran pemakaiannya. Fungsi-fungsi yang sebelumnya dimiliki oleh bahasa Bugis sudah diambil alih oleh bahasa Bali dan sebagian kecil oleh bahasa Indonesia.

3. Faktor-faktor yang menyebabkan terjadinya pergeseran bahasa Bugis di Desa Senganan ada dua, yaitu faktor internal dan faktor eksternal. Faktor internal meliputi: kesinambungan pengalihan bahasa ibu, proses adaptasi/pembauran, dan sikap bahasa masyarakat Bugis ; faktor eksternal meliputi lingkungan geografis pemukiman dan lingkungan alam sekitar (ekologi bahasa).

\section{DAFTAR PUSTAKA}

Fasold, R. (1984). The sociolinguistic of society. Oxford: Basil Blackwell.

Fishman, J. A. (1972). Readings in the sociology of language. Paris: Mouton.

Katalina, D. (2000). Strategi bepartite komunitas cina di desa pupuan. Universitas Udayana.

Mahsun. (2013). Metode penelitian bahasa tahapan strategi, metode, dan tekniknya. Jakarta: Rajawali Pers.

Suandi. (2014). Sosiolinguistik. Yogyakarta: Graha Ilmu.

Sudaryanto. (1993). Metode dan aneka teknik analisis bahasa. Jakarta: Duta Wacana University Press.

Sumarsono. (1990). Pemertahanan bahasa melayu loloan di Bali. Jakarta: Pustaka Bahasa. 